\title{
Increasing the accuracy of the effect of processing materials and cutting tool wear on the ploughing force values
}

Dugin Andrey, Popov Alexey

Department of Machining and Assembly Faculty of Mechanical Engineering Technical University of Liberec, andrey.dugin@seznam.cz; alespopov@yandex.ru

The determination of the ploughing forces is necessary for wear monitoring of the cutting tool in micro cutting. The extrapolation method on zero cut chip thickness is used very often to determine the ploughing forces. But there are many opponents of the extrapolation method on zero uncut thickness. The aim of this research was to increase the accuracy of determination of the ploughing force and to investigate the effect of processing materials and cutting tool wear on the ploughing force values. To achieve this aim was used the method comparing total forces at different flank levels of wear to determine the ploughing forces. The experiments were performed by cutting of aluminum alloys, structural steels and stainless steel with different cutting tool wear.

Keywords: machining, ploughing force, micro cutting

\section{Acknowledgement}

This paper is related to the investigation on the Specific University Research Projects which are supported by the Ministry of Education (MSMT) of the Czech Republic.

\section{References}

[1] ALBRECHT, P., New developments in the theory of the metal cutting processes, Part 1. The ploughing process in metal cutting, ASME J. Eng. Ind., 1960, n.82, p.348-357, ISSN: 0022-0817.

[2] ZOREV, N., Metal cutting mechanisms, Pergamon Press, Oxford, 1966, p.135-180.

[3] DUGIN, A., POPOV, A., Effect of the cutting tool wear on the ploughing force values, Strojírenská Technologie, 2012, n. 17, p. 19-23, ISSN 1211-4162.

[4] TANSEL, I., ARKAN, T., BAO, W., MAHENDRAKAR, N., SHISLER, B., SMITH, D., MCCOOL, M., Tool wear estimation in micro-machining. Part I: tool usage-cutting force relationship, International Journal of Machine Tools \& Manufacture, 2000, n.40 p.599-608, ISSN: 0890-6955.

[5] CHAE, J., PARK, S., FREIHEIT, T., Investigation of micro-cutting operations, International Journal of Machine Tools \& Manufacture, 2006, n.46 p.313-332, ISSN: 0890-6955.

[6] JEMIELNIAK, K., BOMBINSKI, S., ARISTIMUNO. P., Tool condition monitoring in micromilling based on hierarchical integration of signal measures, CIRP Annals, 2008, ISSN: 0007-8506.

[7] ŽIŽKA, J., LINHART, T., Urcovani stavu opotrebeni soustružnickeho nože pomoci pomeru složek rezne sily, Strojirenska technologie, 2009, n. 1, p. 23-28, ISSN 1211-4162.

[8] WYEN, C., WEGENER, K., ZUST, R., Influence of cutting edge radius on cutting forces in machining titanium, CIRP Annals, 2010, ISSN: 0007-8506.

[9] DUGIN, A., POPOV, A., Effect of the processing materials on the ploughing force values, Manufacturing Technology, 2012, Vol. 12, n. 13:102 - 105, ISSN 1213-2489.

[10] POPOV, A., DUGIN, A., A comparison of experimental estimation methods of the ploughing force in orthogonal cutting, International Journal of Machine Tools and Manufacture, 2013, 65:37 - 40, ISSN: 0890-6955.

[11] LIPATOV, A., CHIGIRINSKII, Y., KORMILITSYN, S., Determining the Cutting Forces at the Rear Tool Surface, Russian Engineering Research, 2010, 30(11):1158-1160, ISSN 1068-798X

[12] POPOV, A., DUGIN, A., Experimental Methods of Determining the Cutting Forces at the Tool's Rear Surface, Russian Engineering Research, 2012, Vol. 32, n. 1, p. 68-69, ISSN: 1934-8088.

[13] STEVENSON, R., Measurement of parasitic forces in orthogonal cutting, Int. J. Mach. Tools Manuf., 1998, n.38 p.113-130, ISSN 0890-6955.

[14] KASINA, M., VASILKO, K., Experimental Verification of the Relation between the Surface Roughness and the Type of Used Tool Coating, Manufacturing Technology, 2012, n.12, ISSN 1213-2489. 